\title{
Decisions of stakeholders for the proposed artificial reef deployment: Analytic hierarchy process approach
}

\author{
Yerleştirilmesi amaçlanan yapay resifler için paydaşların kararları: Analitik \\ hiyerarşi süreci yaklaşımı
}

\author{
Sezgin Tunca1* ${ }^{1 *}$ Bülent Miran² Vahdet Ünal $^{3}$

\begin{abstract}
${ }^{1}$ Muğla University, Faculty of Fisheries, Department of Fishery and Fish Processing Technology, 48000, Kötekli, Muğla, Turkey ${ }^{2}$ Ege University, Faculty of Agriculture, Department of Agricultural Economics, 35100, Bornova, lizmir, Turkey ${ }^{3}$ Ege University, Faculty of Fisheries, Department of Fishery and Fish Processing Technology, 35100, Bornova, Izmir, Turkey *Corresponding author: sezgin.tunca@gmail.com
\end{abstract}

\begin{abstract}
Özet: Bugüne kadar Türkiye'de yapay resif alanlarının etkin kullanımı ve paylaşımılla ilgili ticari balıkçılar, amatör balıkçılar ve yöre sakinlerini ele alan farklı paydaş gruplarının kararları değerlendirilmemiştir. Bu çalışmada, söz konusu denizel alanla ilgili mevcut durum, yapay resif ve deniz rezervi senaryonlarıı içeren deneysel senaryolarla paydaşların kararlarıı analiz etmek üzere çoklu karar verme sürecinde yaygın olarak kullanılan bir teknik (Analitik Hiyerarşi Süreci) kullanılmış̧ır. Sonuç olarak, yapay resif uygulaması ticari ve amatör balıkçılar tarafından desteklenmiştir. Ancak amaçlanan yapay resif yapılarının gelecek kullanım hakları ile ilgili görüşler araştırma grupları arasında farkllık göstermiştir. Amaçlanan yapay resiflerin farklı paydaş grupları arasında tahsis edilmesi üç grup tarafından da \% 50'nin üzerinde kabul görmüştür. Gelecek çalışmalar için model olacak bu çalışmada yapay resiflerin önemi, potansiyel kullanıcıların yüksek destekleme eğilimiyle ekonomik, biyolojik ve sosyal faydaları ele alınarak ortaya koyulmuştur.
\end{abstract}

Anahtar kelimeler: Yapay resifler, Paydaşlar, Analitik Hiyerarşi Süreci, Karar verme.

\begin{abstract}
Decisions of different stakeholders which includes commercial fishermen, recreational fishermen and local residents through efficient use and share of artificial reefs sites were not been assessed up to present in Turkey. With the commonly used technique for multi-cirteria decision making process (Analytic Hierarchy Process) was used to analyze stakeholder decision through experimental scenarios which includes current status, artificial reef deployment and marine reserve related to marine area in question. In result, artificial deployment act was supported by commercial and recreational fishermen; however, opinions through future use rights of purposed artificial reef structures were diversified among study groups. Allocation of proposed AR sites among different stakeholders were agreed by three focus groups with acceptance at rates over $50 \%$. Importance of artificial reefs were presented by accounting economic, biologic, social benefits and management gaps with high tendecy of support by potantial direct users in this study, which is also thought to be a model for future studies.
\end{abstract}

Keywords: Artificial reefs, Stakeholders, Analytic Hierarchy Process, Decision making.

\section{INTRODUCTION}

Artificial reefs (ARs) were introduced as good example of fish enhancement tool in marine area. Beyond fish enhancement, ARs creates services for scuba divers and recreational fishermen that explain its great importance in terms of economic and social aspects. (Asafu-Adjaye and Tapsuwan, 2008; Ditton et al., 2002; Hiett and Milon, 2002; Milon, 1988; Morgana et al., 2008; Oh et al., 2008; Pendleton, 2004, Sutton and Bushnell, 2007). With a wide range of AR deployment acts, use rights of ARs sites were not assesed deeply by adding assessing stakeholders' opinions through socioeconomic researches in Turkey. Socioeconomics researches conducted in other countries, especially in United States, showed great economic contribution of ARs (Whitmarsh et al., 2008; Milon et al., 2000; Johns et al., 2001). However, freedom of use in AR sites were thought to create conflicts among different stakeholders such as commercial fishermen (CF), recreational fishermen (RF), recreational (๑) Published by Ege University Faculty of Fisheries, Izmir, Turkey divers (RD), local residents (LR). Therefore, seperate use styles or specific purposes on ARs, without transparency, control and management in use may result in conflicts among stakeholders.

General attitudes and opinions of individuals under certain conditions which can be related to developing a new policy, establishing a new commercial facilty or simply buying a house is naturally been assessed through different alternatives. Individual decisions can be considered to depended on background that includes occupation, education level and hobbies. Generally, with an Analytic Hierarchy Process (AHP) Method, as we are all fundamentally decision makers (Saaty, 2008), to be able create coherent management plans and environmentally sustainable AR areas, it is possible to analyse stakeholders' attitudes towards use of AR sites. 
The general aim of this study is to analyze stakeholder decision through experimental scenarios which includes current status, AR deployment and marine reserve establishment related to marine area in question via Analytic Hierarchy Process Methodology. Under three three scenarios, possible AR related activities that considered as alternatives including recreational fishing, commercial fishing, conservation of the marine zone, scuba diving and decreasing conflicts among stakeholders were also analyzed. Mainly, this study aims to put forward the importance of future ARs by comparing different scenarios. In addition, different use types and issues in the scenario of ARs' deployment were also planned to assess.

\section{MATERIALS AND METHOD}

Within the scope of the study, firstly, related national and international scientific literature was reviewed then field studies which were planned to draw a picture of the current status of ARs' stakeholders were conducted in Altınoluk where is the pilot AR deployment site in the National Artificial Reef Project of Turkey. Questionnaire based face-to-face interviews were planned to collect data from target survey groups (CF, $\mathrm{RF}, \mathrm{LR}$ ) who were determined to be the most relevant group with the future ARs. Three different specially designed questionnaire forms were used for each group. Representative sample size was calculated for each group because of the time and budget constraints according to $95 \%$ confidence interval and 5\% tolerance interval (Miran, 2003). Sample size was determined as 20 CF who are the members of Altınoluk Fishery Cooperative ( $\mathrm{N}=55$ ) (Halil Ataç, personal communication, April, 2011), 58 RF who participate recreational fishing on shore or on a boat in Altınoluk ( $N=400)$ (Halil Ataç, personal communication, April, 2011), 67 LR in Altınoluk $(\mathrm{N}=13,800)$ (TSI, 2011). Proportional sampling size formula was used for proper sampling from three groups. Sampling sizes for each group were determined by the fraction below (Miran, 2003).

$$
n=\frac{N p(1-p)}{(N-1) \sigma_{p x}^{2}+p(1-p)}
$$

where $n$ is the sample sizes of each group for face-to-face questionnaire surveys, $\mathrm{N}$ is the total population of each target group (CF, RF, LR), $p$ is the contribution ratio to ARs ( 0.50 is fitted to reach maximum sample size) and $\sigma p x 2$ is the variance considered according to the frequency of the issue $( \pm 0.05)$.

In the questionnaire surveys, data on demographic, socioeconomic dimensions of the respondents and the priorities given by target groups for different criterions and alternatives in the experimental AHP scenario were collected.

\section{Analytic Hierarchy Process (AHP)}

Within the study, AHP method was used to determine users's choices for different scenarios including current status,
AR deployment and marine reserve establishment. With the AHP study, users's attitudes towards ARs can be assessed deeply.

Generally, AHP is a choice process from different alternatives to reach goals and targets (Forman and Selly, 2000). This method is developed by Thomas L. Saaty (1980) and was used for solutions of complicated problems. It creates a modeling opportunity in hierarchical structure that shows relationship among main goal, criterions, subcriterions and alternatives (Saaty et al., 2003). Hierarchical organization of criterions is commonly used in extensive decision problems. It was proven that human brain can not operated more than seven stimulants in a certain time and it was also proven that human mind can not compare more than three criterions in the same time (Prakash, 2003).

AHP is composed of three main principals which are decomposition, pair-wise comparison and hierarchical arrangement. Decomposition is a process that structures a problem in a variety of hierarchies. Pair-wise comparison is a pair-wise comparison matrix composition process which provides us to make dual comparisons between alternatives and criterions. Hierarchical arrangement is a composition process of comparisons on hierarchy.

First step of AHP is decomposition of decision problem to main components and composing a hierarchical structure. This helps decision makers to focus on small components of relevant decision (Braunschweig and Becker, 2004). On the top of the decision hierarchy, main goal, on one step below criterion that will affect quality of decision and on the bottom step, decision alternatives are placed (Figure 1).

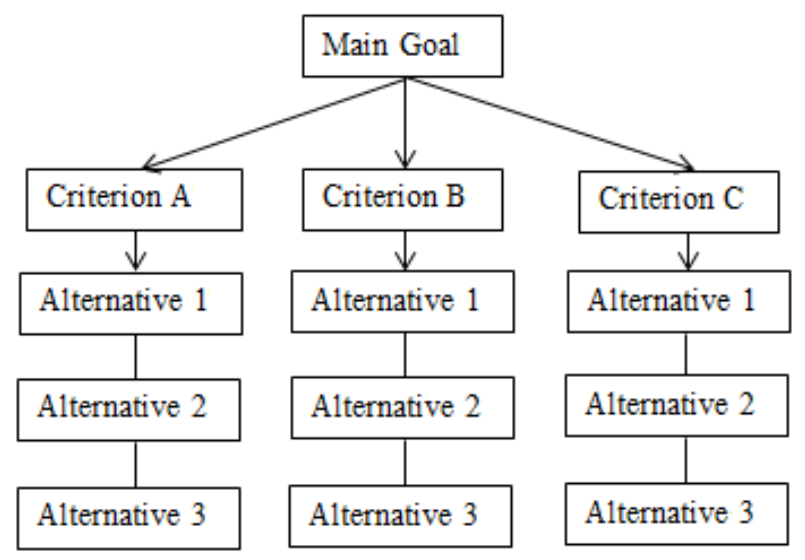

Figure 1. General view of AHP model (Saaty, 1980).

Pair-wise comparisons compose the second step of AHP. That means two alternatives or criterions will be compared and it is based on judgement of decision maker. If the hierarchy includes components (alternatives), totally, it is necessary to make $n(n-1) / 2$ comparisons. In the pair-wise comparison, importance degree of $A$ criterion according to $B$ criterion is determined by choice scale from 1 to 9 demonstrated in Table 1 (Saaty, 1980). 2, 4, 6, 8 values in the 
preference scale are interval rates. Calculation of each compared component is called synthesization. Synthesization process includes normalization.

In the most commonly used normalization method, components of each column are divided by sum of the column. During this process, to achieve the main goal of the problem, a mixed priorities vector is composed to serve as arrangement of decision alternatives. Final priorities are called as points of decision alternatives.

Table 1. Standard preference scale used in AHP (Saaty, 1990)

\begin{tabular}{|c|c|c|}
\hline Intensity of importance Definition Explanation & Intensity of importance Definition Explanation & Intensity of importance Definition Explanation \\
\hline 1 & Equal importance & Two activities contribute equally to the objective \\
\hline 3 & Moderate importance of one over another & $\begin{array}{l}\text { Experience and judgment strongly favor one activity } \\
\text { over another }\end{array}$ \\
\hline 5 & Essential or strong importance & $\begin{array}{l}\text { Experience and judgement strongly favor one activity } \\
\text { over another }\end{array}$ \\
\hline 7 & Very strong importance & $\begin{array}{l}\text { An activity is strongly favored and its dominance } \\
\text { demonstrated in practice }\end{array}$ \\
\hline 9 & Extreme importance & $\begin{array}{l}\text { The evidence favoring one activity over another is of } \\
\text { tile highest possible order of affirmation }\end{array}$ \\
\hline $2,4,6,8$ & $\begin{array}{l}\text { Intermediate values between the two adjacent } \\
\text { judgments }\end{array}$ & When compromise is needed \\
\hline Reciprocals & \multicolumn{2}{|c|}{$\begin{array}{l}\text { If activity } i \text { has one of the above numbers assigned to it when compared with activity } j, \text { then, } j \text { has the } \\
\text { reciprocal value when compared with } i\end{array}$} \\
\hline Rationals & Ratios arising from the scale & $\begin{array}{l}\text { If consistency were to be forced by obtaining } \\
\text { numerical values to span the matrix }\end{array}$ \\
\hline
\end{tabular}

There are many studies considering a wide range of disciplines were conducted using AHP. These studies can be described shortly as follow:

These studies are concerning agricultural production (Alphonce, 1997; Mainuddin et al., 1997; Guo and He, 1999; Kahraman et al., 2003; Prakash, 2003; Qureshi and Harrison, 2003; Braunschweig and Becker, 2004; Gómez-Limón and Atance, 2004; Karami, 2006; Parra-López and CalatravaRequena, 2006; Simona and Romana, 2006; Gómez-Limón and Riesgo, 2008; Günden and Miran, 2008; RezaeiMoghaddam and Karami, 2008) whereas others regarding consumption and marketing issues of food (Kahraman et al., 2004; Kauko, 2006; Ko and Chiu, 2006; Kong and Liu, 2005; Wang et al., 2007; Günden et al., 2008) and lastly, Ramos et al. (2006) assessed reef diving choices by accounting factors including biological, geographical, atmospheric, economic, incentive.

\section{Tobit Model}

Tobit model is an extension of probit model. It is placed among limited dependent variable models (Gujarati, 2004). In this model, dependent variable, $Y$ holds an asymmetry between positive and negative or 0 values (Ramanathan, 1998). Common formulation of tobit model, as is probit model, is given based on an index function below (Greene, 2003).

$$
\begin{aligned}
& Y_{i}^{*}=\beta^{\prime} X_{i}+u_{i}, \\
& \text { If } \quad Y_{i}^{*}<=0 \text { ise } Y_{i}=0 \\
& \text { If } \quad Y_{i}^{*}<0 \text { ise } Y_{i}^{*}=0
\end{aligned}
$$

As is in probit model, estimators in probit model are calculated by maximum likelihood method (Gujarati, 2004).

Within the study, factors affecting priorities given to criterions and alternatives by the respondents were assessed seperately via using tobit regression analysis.

\section{RESULTS}

\section{Hierarchical Order and AHP Results}

In the AHP diagram, effective use of marine zone was determined as main goal. Then, fixed criterions and alternatives designed for CF, RF and LR were evaluated, seperately. Explanations regarding considered criterions and alternatives were stated as follow. Firstly, current status criterion was described as first scenario. On the other side, it was proposed to deploy ARs under National AR Project of Turkey with the AR deployment criterion. And, finally, marine reserve establishment critrerion was described and proposed as a marine zone which is controlled under good management practice in terms of commercial fishing, recreational fishing, recreational trips and recreational diving activities. For each criterion, five alternatives which includes recreational fishing, commercial fishing, conservation of the marine zone, scuba diving activities, decreasing conflicts among stakeholders were assessed by pair-wise comparisons. Priorities given to different alternatives were then evaluated. Figure 2 describes the AHP decision making tree used in this study. 


\section{AHP Priorities for Research Groups}

\section{CF}

Priorities of CF for criterions were specified after pair-wise comparisons. To define priorities for each criterion, mean priority values extracted from mathematical calculations for each criterion was analyzed. First, mean priority value of CF was determined as $0.63( \pm 0.22)$ for AR deployment. Then, secondly, $0.29( \pm 0.20)$ for marine reserve and lastly, 0.07 $( \pm 0.07)$ for current status. This results show that CF pays high attention and prefer to AR deployment (Table 2).

On the other side, general results of priorities given to five alternatives were as follow for CF: conservation of the marine zone, $0.44( \pm 0.12) ;$ commercial fishing, 0.22 ( \pm 0.11$)$; decreasing conflicts among stakeholders, 0.18 ( \pm 0.09$)$; recreational fishing, $0.08( \pm 0.06)$; scuba diving activities, 0.07 $( \pm 0.06)$. At the same time, priorities given to five alternatives were assessed for each criterion. For current status, AR deployment and marine reserve establishment scenarios, results did not show significant difference among priorities given by CF (Table 2).

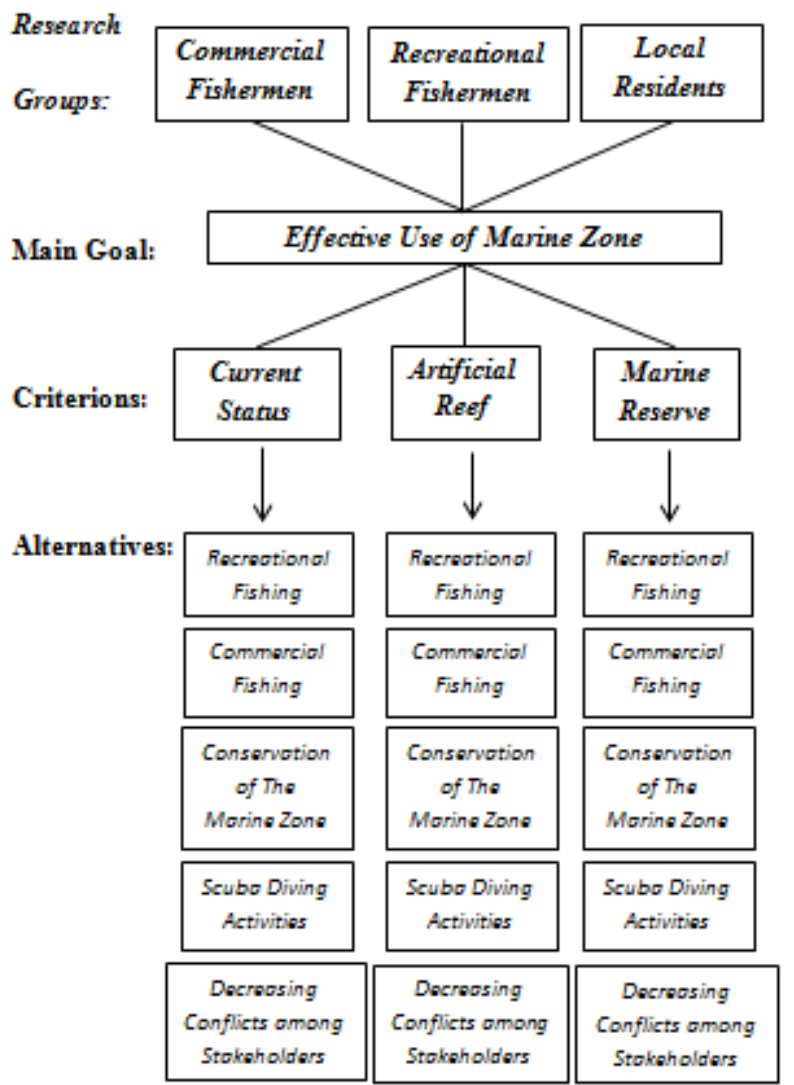

Figure 2. AHP scheme used in the study

$$
\text { RF }
$$

According to the results obtained from pair-wise comparisons, firstly, criterions were assesed for RF. As in the case of $\mathrm{CF}$, among three criterions, RF also gave first priority to AR deployment, $0.59( \pm 0.19)$; second priority to marine reserve establishment, $0.35( \pm 0.19)$, scenarios and last priority, current status, $0.07( \pm 0.04)$. General results for five different alternatives were assessed via pair-wise comparisons in which conservation of the marine zone, 0.42 $( \pm 0.13)$ got the highest rank, and orderly, other ranking values were found as recreational fishing, $0.20( \pm 0.11)$; decreasing conflicts among stakeholders, $0.21( \pm 0.12)$; scuba diving activities, $0.10( \pm 0.06)$, commercial fishing, $0.07( \pm 0.09)$. For each criterion, priorities given to different alternatives were also analysed. And no distinctive difference was determined as in the case of RF (Table 3).

Table 2. Priorities given by CF

\begin{tabular}{lccccc}
\hline Criterions & $\begin{array}{c}\text { Recreational } \\
\text { Fishing }\end{array}$ & $\begin{array}{c}\text { Fommercial } \\
\text { Fishing }\end{array}$ & $\begin{array}{c}\text { Conservation } \\
\text { of the Marine } \\
\text { Zone }\end{array}$ & $\begin{array}{c}\text { Scuba } \\
\text { Diving } \\
\text { Activities }\end{array}$ & $\begin{array}{c}\text { Decreasing } \\
\text { Conflicts } \\
\text { among } \\
\text { stakeholders }\end{array}$ \\
\hline $\begin{array}{l}\text { Current } \\
\text { Status }\end{array}$ & 0.10 & 0.22 & 0.40 & 0.07 & 0.20 \\
$\begin{array}{l}\text { Artificial } \\
\text { Reef } \\
\text { Marine }\end{array}$ & 0.09 & 0.22 & 0.44 & 0.06 & 0.18 \\
Reserve & 0.07 & 0.22 & 0.43 & 0.09 & 0.19 \\
\hline
\end{tabular}

Table 3. Priorities given by RF

\begin{tabular}{lccccc}
\hline Criterions & $\begin{array}{c}\text { Recreational Commercial } \\
\text { Fishing }\end{array}$ & $\begin{array}{c}\text { Conservation } \\
\text { Fishing }\end{array}$ & $\begin{array}{c}\text { Scuba } \\
\text { of Marine } \\
\text { Ziving }\end{array}$ & $\begin{array}{c}\text { Decreasing } \\
\text { Activities } \\
\text { Conflicts } \\
\text { among } \\
\text { stakeholders }\end{array}$ \\
\hline $\begin{array}{l}\text { Current } \\
\text { Status }\end{array}$ & 0.17 & 0.07 & 0.45 & 0.10 & 0.21 \\
$\begin{array}{l}\text { Artificial } \\
\text { Reef } \\
\text { Marine }\end{array}$ & 0.21 & 0.07 & 0.42 & 0.10 & 0.21 \\
Reserve & 0.20 & 0.06 & 0.42 & 0.12 & 0.20 \\
\hline
\end{tabular}

$L R$

Priorities given to three criterions was assessed for LR, and first priority was given to marine reserve establishment, 0.46 ( \pm 0.21$)$; second priority to AR deployment, $0.45( \pm 0.21)$, and last priority to current status, $0.09( \pm 0.12)$ by LR. For five alternatives, as in the case of $\mathrm{CF}$ and RF, conservation of the marine zone, $0.38( \pm 0.39)$, got the highest rank; however, other ranking values were found as $0.19( \pm 0.17)$ for scuba diving activities, $0.19( \pm 0.18)$ for decreasing conflicts among stakeholders; $0.17( \pm 0.16)$ for recreational fishing and 0.06 $( \pm 0.05)$ for commercial fishing. For each criterion, LR gave the first priority to the conservation of the marine zone while scuba diving activities got the second priority in the situations of marine reserve establishment and AR deployment, and the third priority in the case of current status. Decreasing conflicts among stakeholders got second priority in the case of current status and AR deployment, at the same time, for marine reserve establishment criterion, it got third rank among alternatives. For each three criterions, commercial fishing 
were stated as last priority and ranked higher than recreational fishing and (Table 4).

Table 4. Priorities given by LR

\begin{tabular}{lccccc}
\hline Criterions & $\begin{array}{c}\text { Recreational Commercial } \\
\text { Fishing }\end{array}$ & $\begin{array}{c}\text { Conservation } \\
\text { of the Marine } \\
\text { Zone }\end{array}$ & $\begin{array}{c}\text { Scuba } \\
\text { Diving } \\
\text { Activities }\end{array}$ & $\begin{array}{c}\text { Decreasing } \\
\text { Conflicts } \\
\text { among } \\
\text { stakeholders }\end{array}$ \\
\hline $\begin{array}{l}\text { Current } \\
\text { Status }\end{array}$ & 0.14 & 0.10 & 0.38 & 0.16 & 0.21 \\
$\begin{array}{l}\text { Artificial } \\
\text { Reef } \\
\text { Marine } \\
\text { Reserve }\end{array}$ & 0.17 & 0.06 & 0.39 & 0.19 & 0.19 \\
\hline
\end{tabular}

Analysis of Alternatives and Criterions via Tobit Regression

Results for each criterion and alternatives that range between 0-1 were anaysed to find out statistically significant socioeconomic variables of local residents via tobit regression analysis. Definitions and descriptives of dependent and independent variables are respectively described in Table 5 and in Table 6 . Variables affecting priority level given to criterions and alternatives were also analyzed, orderly (Table 7).

For recreational fishing alternative, a positive reletionship between education level and recreational fishing variables were detemined. However, respondents who have social security gave higher priority to recreational fishing and respondents who know about national AR project gave lower priority to recreational fishing (Table 7).

For commercial fishing alternative, it was found that commercial fishing was positively related to these two variables, being environmentalist that was analyzed via new environmental paradigm and total family population (Table 7).

For conservation of the marine zone alternative, having a social security and being environmentalist were found to be positively related to choosing conservation of the marine zone alternative which is, however, negatively related to the house ownership (Table 7).

Table 5. Dependent and independent variables used for tobit models

\begin{tabular}{|c|c|c|}
\hline & Variable & Definition \\
\hline \multirow{12}{*}{ 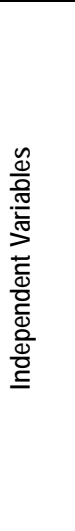 } & Age & Respondents' age ( $1: \leq 25,2: 26-45,3: 46-60,4: 61 \leq)$ \\
\hline & Education & Respondents' education level ( $1: 1-5,2: 6-8,3: 9-11,4: 12 \leq)$ \\
\hline & Social Security & Social security status of individuals (1:Yes; $0: \mathrm{No})$ \\
\hline & Income & $\begin{array}{l}\text { Respondents' monthly income ( 1: } \leq 500 \mathrm{TL}, 2: 501-1000 \text { TL, 3:1001-1500 TL, 4:1501-2000 TL, 5:2001-2500 TL, 6:2501-3000 } \\
\text { TL, 7:3001-3500 TL, 8: } 3500 \text { TL } \leq \text { ) }\end{array}$ \\
\hline & ResInd & Number of Individuals respondents' are responsible to take care of \\
\hline & Fampop & Respondents' total family population \\
\hline & OwnHouse & Respondents' house ownership status (1:Yes; 0:No) \\
\hline & HeardReef & Respondents' status of knowledge about AR concept (1:Yes; 0:No) \\
\hline & HeardPro & Respondents' status of knowledge about national AR project (1:Yes; 0:No) \\
\hline & NEP & $\begin{array}{l}\text { Respondents' Environmental attitudes under New Environmental Paradigm (NEP) (1:Absolutely non-environmentalist; 5: } \\
\text { Absolutely environmentalist; 1-5 scale) }\end{array}$ \\
\hline & TRA & Number of days in a year that respondents attend to a recreational activity (trip, diving, recreational fishing) \\
\hline & AfReef & Number of visits that respondents' are willing to do after reef deployment \\
\hline \multirow{5}{*}{ 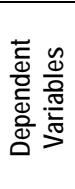 } & RF & Priority given to recreational fishing \\
\hline & CF & Priority given to commercial fishing \\
\hline & CMZ & Priority given to conservation of the marine zone \\
\hline & DIVE & Priority given to scuba diving activities \\
\hline & DECON & Priority given to decreasing conflicts among stakeholders \\
\hline
\end{tabular}

For scuba diving activities alternative, it was determined that respondents who are responsible to look after more than two individuals gave lower priority to scuba diving activities. In addition, negative relationship was found between scuba diving activities and being environmentalist. And, respondents who have a house and respondents who heard about AR concept gave higher priority to scuba diving activities alternative. Lastly, total recreational activity days were positively related to scuba diving activities alternative. For decreasing conflicts among stakeholders alternative, total recreational activity days and being heard about national AR project were found to have positive relationship (Table 7).

For current status criterion, unexpectedly, respondents who indicated to attend more recreational activities after AR deployment gave higher priority to current status criterion. For AR deployment criterion, respondents who have knowledge about national AR project gave higher priority to AR deployment. For marine reserve criterion, respondents who are willing to attend more recreational activities after AR deployment gave higher priority to marine reserve criterion (Table 8). 
Table 6. Descriptives of dependent and independent variables used for tobit models

\begin{tabular}{lcccc}
\hline \multicolumn{1}{c}{ Variable } & Mean & Std. Dev. & Min & Max \\
\hline RF & 0.17 & 0.09 & 0.03 & 0.42 \\
CF & 0.07 & 0.05 & 0.02 & 0.25 \\
CMZ & 0.38 & 0.13 & 0.11 & 0.63 \\
DIVE & 0.19 & 0.10 & 0.04 & 0.49 \\
DECON & 0.19 & 0.11 & 0.03 & 0.52 \\
CS & 0.09 & 0.12 & 0.05 & 0.77 \\
AR & 0.45 & 0.21 & 0.05 & 0.75 \\
MR & 0.46 & 0.21 & 0.05 & 0.78 \\
Age & 2.25 & 0.70 & 1 & 4 \\
Education & 2.84 & 0.96 & 1 & 4 \\
SocSec & 0.81 & 0.40 & 0 & 1 \\
Income & 1.52 & 0.59 & 0 & 3 \\
ResInd & 0.22 & 0.42 & 0 & 1 \\
Fampop & 0.48 & 0.50 & 0 & 1 \\
OwnHouse & 0.55 & 0.50 & 0 & 1 \\
HeardReef & 0.46 & 0.50 & 0 & 1 \\
HeardPro & 0.09 & 0.29 & 0 & 1 \\
NEP & 3.89 & 0.46 & 2.77 & 4.69 \\
TRA & 41.37 & 66.98 & 0 & 300 \\
AfReef & 18.18 & 22.65 & 0 & 1045 \\
\hline
\end{tabular}

\section{Management of ARs}

Stakeholders were queried realted to the allocation of $A R$ sites among different stakeholders. $80 \%$ of $\mathrm{CF}, 50 \%$ of RF, $67 \%$ of LR and $62 \%$ of all respondents approved the experimental allocation act for AR sites. Regarding management of ARs, respondents were analyzed for different management authority options. CF highly chose the option of fishery cooperatives with a $80 \%$ rate. On the other side, RF, gave priorities to a reef guard station under ministry (31\%), fishery cooperative $(27.6 \%)$, coast guard station $(10.3 \%)$. Lastly, $30 \%$ of LR rated a reef guard station under ministry, while $16.4 \%$ of the rest gave first priority to both fishery cooperative and a reef guard station.

\section{DISCUSSION}

Generally, desired AR performance should be identified in the early stages of the planning process in order to develop socially, biologically and economically efficient deployment acts. By considering whole picture for this study, focus groups were stated different attitudes for different situtations. With the help of AHP method which is one of the most common used

Table 7. Tobit regression results for alternatives

\begin{tabular}{|c|c|c|c|c|c|c|c|c|c|c|}
\hline & \multicolumn{2}{|c|}{ RF } & \multicolumn{2}{|c|}{ CF } & \multicolumn{2}{|c|}{$\mathrm{CMZ}$} & \multicolumn{2}{|c|}{ DIVE } & \multicolumn{2}{|c|}{ DECON } \\
\hline & Coeff. & Std. Dev. & Coeff. & Std. Dev. & Coeff. & $\begin{array}{l}\text { Std. } \\
\text { Dev. }\end{array}$ & Coeff. & $\begin{array}{l}\text { Std. } \\
\text { Dev. }\end{array}$ & Coeff. & $\begin{array}{l}\text { Std. } \\
\text { Dev. }\end{array}$ \\
\hline Age & 0.00 & 0.02 & -0.01 & 0.01 & 0.01 & 0.02 & -0.02 & 0.01 & 0.02 & 0.02 \\
\hline Education & $0.03^{\star *}$ & 0.01 & 0.01 & 0.01 & -0.01 & 0.02 & 0.00 & 0.01 & $-0.03^{*}$ & 0.01 \\
\hline SocSec & $0.05^{*}$ & 0.03 & -0.01 & 0.02 & $0.08^{\star \star}$ & 0.03 & $-0.09 * \star \star$ & 0.02 & -0.03 & 0.03 \\
\hline Income & -0.02 & 0.02 & 0.00 & 0.01 & 0.03 & 0.03 & -0.01 & 0.02 & 0.00 & 0.02 \\
\hline ResInd & -0.02 & 0.03 & -0.03 & 0.02 & 0.03 & 0.04 & $-0.05^{\star *}$ & 0.02 & $0.07^{*}$ & 0.04 \\
\hline Fampop & 0.02 & 0.02 & $0.03^{* *}$ & 0.02 & -0.05 & 0.03 & 0.02 & 0.02 & -0.02 & 0.03 \\
\hline OwnHouse & -0.01 & 0.02 & -0.01 & 0.01 & $-0.07^{\star *}$ & 0.03 & 0.05 & 0.02 & 0.03 & 0.03 \\
\hline HeardReef & 0.02 & 0.02 & 0.01 & 0.02 & -0.04 & 0.03 & $0.06^{\star \star \star}$ & 0.02 & -0.06 & 0.03 \\
\hline HeardPro & $-0.12^{\star \star \star}$ & 0.03 & -0.02 & 0.02 & 0.05 & 0.05 & -0.03 & 0.03 & $0.12^{* *}$ & 0.04 \\
\hline NEP & 0.01 & 0.02 & $0.03^{*}$ & 0.02 & $0.07^{\star \star}$ & 0.03 & $-0.07^{\star \star \star}$ & 0.02 & -0.04 & 0.03 \\
\hline TRA & 0.00 & 0.00 & 0.00 & 0.00 & 0.00 & 0.00 & $0.00 * * *$ & 0.00 & 0.00 ** & 0.00 \\
\hline AfReef & 0.00 & 0.00 & 0.00 & 0.00 & 0.00 & 0.00 & 0.00 & 0.00 & 0.00 & 0.00 \\
\hline Sabit & 0.03 & 0.10 & -0.07 & 0.07 & 0.11 & 0.14 & 0.52 & 0.09 & 0.41 & 0.13 \\
\hline sigma | & 0.07 & 0.01 & 0.05 & 0.00 & 0.10 & 0.01 & 0.06 & 0.01 & 0.09 & 0.01 \\
\hline Logarithmic Likelihood & \multicolumn{2}{|c|}{79.77} & \multicolumn{2}{|c|}{111.13} & \multicolumn{2}{|c|}{61.40} & \multicolumn{2}{|c|}{92.29} & \multicolumn{2}{|c|}{65.90} \\
\hline $\begin{array}{l}\text { Likelihood Ratio } \\
\text { Chi-Squared }\end{array}$ & \multicolumn{2}{|c|}{26.71} & \multicolumn{2}{|c|}{16.12} & \multicolumn{2}{|c|}{34.61} & \multicolumn{2}{|c|}{68.17} & \multicolumn{2}{|c|}{29.49} \\
\hline Probability > Chi-Squared & \multicolumn{2}{|c|}{0.01} & \multicolumn{2}{|c|}{0.19} & \multicolumn{2}{|c|}{0.00} & \multicolumn{2}{|c|}{0.00} & \multicolumn{2}{|c|}{0.00} \\
\hline
\end{tabular}

*** Coefficient significant at $P \leq 0.05$ or better.

** Coefficient significant at $P \leq 0.05$ or better.

* Coefficient significant at $P \leq 0.10$ or better.

Number of observations: 67 
Table 8. Tobit regression results for criterions

\begin{tabular}{|c|c|c|c|c|c|c|}
\hline & \multicolumn{2}{|c|}{ CS } & \multicolumn{2}{|c|}{ AR } & \multicolumn{2}{|c|}{ MR } \\
\hline & Coeff. & Std. Dev. & Coeff. & Std. Dev. & Coeff. & Std. Dev. \\
\hline Age & -0.01 & 0.02 & 0.04 & 0.03 & -0.03 & 0.04 \\
\hline Education & 0.00 & 0.02 & -0.03 & 0.03 & 0.04 & 0.03 \\
\hline SocSec & -0.02 & 0.03 & & & 0.01 & 0.06 \\
\hline Income & 0.02 & 0.03 & 0.05 & 0.04 & -0.06 & 0.05 \\
\hline ResInd & -0.06 & 0.04 & & & 0.11 & 0.07 \\
\hline Fampop & 0.06 & 0.03 & & & -0.05 & 0.06 \\
\hline OwnHouse & 0.00 & 0.03 & 0.06 & 0.05 & -0.06 & 0.05 \\
\hline HeardReef & 0.04 & 0.03 & 0.03 & 0.06 & -0.08 & 0.06 \\
\hline HeardPro & -0.07 & 0.05 & $0.17^{\star *}$ & 0.08 & -0.10 & 0.08 \\
\hline NEP & $0.09^{\star *}$ & 0.03 & 0.06 & 0.06 & -0.04 & 0.06 \\
\hline TRA & 0.00 & 0.00 & $0.00 *$ & 0.00 & 0.00 & 0.00 \\
\hline AfReef & $0.00^{* * *}$ & 0.00 & & & $0.00^{\star *}$ & 0.00 \\
\hline Constant & -0.31 & 0.14 & 0.50 & 0.24 & 0.81 & 0.26 \\
\hline sigma | & 0.10 & 0.01 & 0.18 & 0.02 & 0.18 & 0.02 \\
\hline Logarithmic Likelihood & \multicolumn{2}{|c|}{61.33} & \multicolumn{2}{|c|}{111.13} & \multicolumn{2}{|c|}{19.31} \\
\hline $\begin{array}{l}\text { Likelihood Ratio } \\
\text { Chi-Squared }\end{array}$ & \multicolumn{2}{|c|}{26} & \multicolumn{2}{|c|}{16.12} & \multicolumn{2}{|c|}{16.68} \\
\hline Likelihood > Chi-Squared & \multicolumn{2}{|c|}{0.01} & \multicolumn{2}{|c|}{0.19} & \multicolumn{2}{|c|}{0.16} \\
\hline
\end{tabular}

*** Coefficient significant at $P \leq 0.05$ or better.

** Coefficient significant at $P \leq 0.05$ or better.

* Coefficient significant at $P \leq 0.10$ or better.

Number of observations: 67

approach for decision making process, proposed AR deployment was assessed by comparing some alternative scenarios included as marine reserve establishment and current status for the marine zone in question.

From the results covered for different alternatives for each criterion, it is thought as hard to give realistic priorities for different alternatives. As a result, by considering different alternatives, there was no distinct difference found among three criterions. With a high priority $(0.63 \pm 0.22)$ given by CF for AR deployment criterion as expected, proved actual support of a new AR deployment. Additionally, AR deployment criterion also got highest priority $(0.59 \pm 0.19)$ among RF while LR gave nearly same priorities for marine reserve establishment $(0.46 \pm 0.21)$ and AR deployment $(0.45 \pm 0.21)$ criterions. Additionally, this result can be supported by AR concept knowledge levels of focus groups which queried with a question as 'Have you ever heard of AR concept?', and CF, RF and LR gave 'yes' answer with $80 \%, 79.3 \%$ and $46.3 \%$ shares, respectively. This results show that big difference in terms of AR knowledge levels between LR and other two groups result from fishery cooperative in the region which is crucial point of interaction for CF and RF.
On the other side, current status scenario which is known as no good for future because of overfishing, lack of habitat and high nutrient and alluvion input to the coastal zone from Mount Ida via streams within 1 nautical mile and marine reserve establishment scenario which can be understood as closing areas and which may also not be known well by focus groups even if its function explained during the questionnarie survey that become a missing point for this study, was not considered as first priority by CF and RF.

From the results, it is easy to illustrate high attention of focus groups for conservation of the marine zone criterion with the results found as $0.44 \pm 0.12,0.42 \pm 0.13$ and $0.38 \pm 0.39$ for $\mathrm{CF}, \mathrm{RF}$ and LR, orderly. As expected, for second priority, CF ranked commercial fishing which is choosen as last priority by RF and LR while RF chose recreational fishing. However, scuba diving activities, decreasing conflicts among stakeholders and recreational fishing got nearly the same priorities after conservation for the marine zone alternative by LR. The results showed that different priorities given by three research group is a representative to show the conflicting opinions for the future use of proposed AR deployment, one side from the different use types and the other side from the 
conservation and decreasing conflicts among stakeholders in the marine zone.

Relationships between criterions and alternatives within the AHP scheme and socioeconomic variables of respondents was put forward via tobit analysis for each alternative. First, education level and social security ownership of respondents were found to be positvely correlated with choosing recreational fishing alternative. Being environmentalist that was analyzed via new environmental paradigm and total family population were found as positively related to commercial fishing alternative. As expected, conservation of the marine zone alternative were found to be positively related to having a social security and being environmentalist alternatives.

For scuba diving activities alternative, it was determined that respondents who are responsible to look after more than two individuals gave lower priority to scuba diving activities. In addition, negative relationship was found between scuba diving activities and being environmentalist. And, respondents who have a house and respondents who heard about AR concept gave higher priority to scuba diving activities alternative. Lastly, total recreational activity days were positively related to scuba diving activities alternative. For decreasing conflicts among stakeholders alternative, total recreational activity days and being heard about national AR project were found to have positive relationship. Respondents who attend more total recreational activities showed tendency to attend more scuba diving activities.

For current status criterion, unexpectedly, respondents who indicated to attend more recreational activities after AR

\section{REFERENCES}

Alphonce, C., 1997. Application of the analytic hierarchy process in agriculture in developing countries. Agricultural Systems, 53:97-112. doi:10.1016/S0308-521X(96)00035-2

Asafu-Adjaye, J., Tapsuwan, S., 2008. A contingent valuation study of scuba diving benefits: Case study in Mu Ko Similan Marine National Park. Tourism Management, 29(6):1122-1130. doi:10.1016/j.tourman.2008.02.005

Braunschweig, T., Becker, B., 2004. Choosing research priorities by using the analytic hierarchy process: an application to international agriculture. R\&D Management, 34:77-86. doi:10.1111/j.1467-9310.2004.00324.x

Ditton, R.B., Osburn, H.R., Baker, T.L., Thailing, C.E., 2002. Demographics, attitudes, and reef management preferences of sport divers in offshore Texas waters. ICES Journal of Marine Science, 59:186-191. doi:10.1006/jmsc.2002.1188

Forman, E.H., Selly, M.A., 2000. Decision by Objectives, How to Convince Others That You are Right. World Scientific. Singapore, 402 p.

Gómez-Limón, J., Atance, I., 2004. Identification of public objectives related to agricultural sector support. Journal of Policy Modeling, 26:1045-1071. doi:10.1016/j.jpolmod.2004.07.005

Gómez-Limón, J.A., Riesgo, L., 2008. Alternative approaches on constructing a composite indicator to measure agricultural sustainability. The Proceedings of the 107th EAAE Seminar. "Modelling of Agricultural and Rural Development Policies". January 29th-February 1st, Sevilla, Spain. $324 \mathrm{p}$. deployment gave higher priority to current status criterion, and this can be as a result of perception bias of respondents. On the other side, respondents who have knowledge about national AR project gave higher priority to AR deployment.

Under results obtained from a deep survey of stakeholders for a proposed AR deployment, the main focus point of this paper is to put forward some ideas from the management perspective with an assisstance of testing an experimental scenario. Allocation of proposed AR sites were agreed by three focus groups with acceptance at rates over $50 \%$. Apart from allocation, the most striking result from the survey covered future management authority for ARs. By considering CF who are the main beneficiaries of marine resources deservedly supporting the idea of fishery cooperative for management authority, and $27.6 \%$ of RF are also determined as a supporter of this idea. On the basis of this result, fishery cooperative or cooperatives in the region can be responsible for new AR site. LR who have little knowledge about AR and pilot project, however, questionably, supported the idea of a reef guard station under ministry. Even excluding another beneficiary of a future AR site, recreational divers who doubtless agree management authority under diving club, these three groups showed us distinct conflict with a questionable result which supports the idea of fishery cooperative for management authority.

For the long term sustainable use of AR sites, it is crucial to determine an effective management authority that is also provide transparancy in use rights. Finally, this preliminary study regarding management perspectives of AR sites, can be a starting point to think through effective control and management of past and future AR sites in Turkey.

Greene, W., 2003. Econometric Analysis. 5th ed. Prentice Hall. New Jersey. $206 \mathrm{p}$.

Gujarati, N.D., 2004. Basic Econometrics. McGraw-Hill. Forth Edition, USA.

Guo, L.S., He, Y.S. 1999. Integrated multi-criteria decision model: a case study for the allocation of facilities in Chinese agriculture. Journal of Agricultural Engineering Research, 73:87-94. doi:10.1006/jaer.1998.0393

Günden, C., Miran, B., 2008. Analysis of Farmers' Fundemantal Farm Management Decisions in Terms of Priority and Getting Support (in Turkish with English abstract). Tekirdağ Ziraat Fakültesi Dergisi, 5(2):6780.

Günden, C., Miran, B., Uysal, Ö.K., Bektaş, Z.K., 2008. Determination of Consumer Preferences for Purchasing Place of Fresh Fruit and Vegetable Considered Food Safety, Quality and Price by using Analytic Hierarchy Process in İmir (in Turkish with English abstract). Finans Politik \& Ekonomik Yorumlar, 45(522):29-40.

Hiett, R., Milon, J.W., 2002. Economic Impact of Recreational fishing and Diving Associated with Offshore Oil and Gas Structures in the Gulf of Mexico. DOI Minerals Management Service Document MMS Study, $10 \mathrm{p}$.

Johns, G., Leeworthy, V.R., Bell, F.W., Bonn, M.A., 2001. Socioeconomic Study of Reefs in Southeast Florida Final Report prepared for MiamiDade County, Florida by Hazen and Sawyer P.C. Miami, FL. 348 p.

Kahraman, C., Cebeci, U., Ulukan, Z., 2003. Multi-criteria supplier selection using fuzzy AHP. Logistics Information Management, 16(6):382-394. doi:10.1108/09576050310503367 
Kahraman, C., Cebeci, U., Ruan, D., 2004. Multi-attribute comparison of catering service companies using Fuzzy AHP: The case of Turkey". International Journal of Production Economics, 87:171-184. doi:10.1016/S0925-5273(03)00099-9

Karami, E., 2006. Appropriateness of farmers' adoption of irrigation methods: The application of the AHP model. Agricultural Systems, 87:101-119. doi:10.1016/j.agsy.2005.01.001

Kauko, T., 2006. Expressions of housing consumer preferences: Proposition for a research agenda housing. Theory and Society, 23(2):92-108. doi:10.1080/14036090600773097

Ko, W.H., Chiu, C.P., 2006. A new coffee shop location planning for customer satisfaction in Taiwan. International Journal of the Information Systems for Logistics and Management (IJISLM), 2(1):55-62.

Kong, F., Liu, H., 2005. Applying fuzzy analytic hierarchy process to evaluate success factors of e-commerce. International Journal of Information and Systems Sciences, 1(3-4):406-412.

Mainuddin, M., Gupta, A., Onta, P., 1997. Optimal crop planning model for an existing groundwater irrigation project in Thailand. Agricultural Water Management, 33:43-62. doi:10.1016/S0378-3774(96)01278-4

Milon, J.W., 1988. Travel Cost Methods For Estimating The Recreational Use Benefits Of Artificial Marine Habitat. Southern Journal Of Agricultural Economics, 87-101.

Milon, J.W., Holland, S.M., Whitmarsh, D.J., 2000. Artificial Reef Evaluation With Application To Natural Marine Habitats. CRC Press. 246 p.

Miran, B., 2003. Basic Statistics (in Turkish). Ege University Press. ISBN 975 9308800, Bornova, İzmir. 297 p.

Morgana, O.A., Massey, D.M., Huth, W.L., Hall, R., 2008. Demand for Diving on Large Ship Artificial Reefs. Marine Resource Economics, 24:43-59.

Oh, C, Ditton, R.B., Stoll, J.R., 2008. The Economic Value of Scuba-Diving Use of Natural and Artificial Reef Habitats. Society \& Natural Resources, 21(6):455-468. doi:10.1080/08941920701681953

Parra-López, C., Calatrava-Requena, J., 2006. A multifunctional comparison of conventional versus alternative olive systems in Spain by using AHP. International Association of Agricultural Economists Conference. Gold Coast, August 12-18, Australia.

Pendleton, L.H., 2004. Creating Underwater Value: The Economic Value of Artificial Reefs for Recreational Diving. Report of Program in Environmental Science and Engineering Department of Environmental Health Sciences University of California, Los Angeles California Artificial Reef Enhancement Division. 234 p.

Prakash, T.N., 2003. Land Suitability Analysis for Agricultural Crops: A Fuzzy Multicriteria Decision Making Approach. Master of Science Thesis. International Institute for Geo-Information Science and Earth Observation. Enschede, The Netherlands. 57 p.
Rezaei-Moghaddam, K., Karami, E., 2008. A multiple criteria evaluation of sustainable agricultural development models using AHP. Environment Development and Sustainability, 10:407-426.

doi:10.1007/s10668-006-9072-1

Qureshi, M.E., Harrison, S.R., 2003. Application of the Analytic Hierarchy Process to piparian revegetation policy options. Small-scale Forest Economics, Management and Policy, 2(3):441-458. doi:10.1007/s11842-003-0030-6

Ramos, J., Santos, M.N., Whitmarsh, D., Monteiro, C.C., 2006. The Usefulness of the Analytic Hierarchy Process for Understanding Reef Diving Choices: A Case Study. Bulletin of Marine Science, 78(1):213219.

Saaty, T.L., 1980. The Analytic Hierarchy Process: Planning Priority Setting. Resource Allocation, McGraw-Hill, New York. 287 p.

Saaty, T.L., 1990. How to make a decision: The Analytic Hierarchy Process. European Journal of Operational Research, 48:9-26. doi:10.1016/0377-2217(90)90057-।

Saaty, T.L., Vargas, L.G., Dellmann, K., 2003. The allocation of intangible resources: the analytic hierarchy process and linear programming. Socio-Economic Planning Sciences, 37:169-184. doi:10.1016/S0038-0121(02)00039-3

Saaty, T.L., 2008. Decision making with the analytic hierarchy process. International Journal of Services Sciences, 1: 83-98. doi:10.1504/IJSSCI.2008.017590

Simona, M., Romana, B., 2006. Multifunctional agriculture: values and preferences of society. International Scientific Days 2006, "Competitivness in the EU Challenge for the V4 countries". Faculty of Economic and Management SAU in Nitra. 267-273.

Sutton, S.G., Bushnell, S.L., 2007. Socio economic aspects of artificial reefs Considerations for the Great Barrier. Ocean \& Coastal Management, 50:829-846. doi:10.1016/j.ocecoaman.2007.01.003

Turkish Statistical Institute (TSI), 2011. The Results of Address Based Population Registration System. <www.tuik.gov.tr>

Wang, M., Liu, P., Ou, G., 2007. The Evaluation study of customer satisfaction based on gray-AHP Method for B2C Electronic-Commerce Enterprise. Engineering Letters, 15(1):157-162.

Whitmarsh, D, Santos, M.N., Ramos, J., Monteiro, C.C., 2008. Marine habitat modification through artificial reefs of the Algarve (southern Portugal): An economic analysis of the fisheries and the prospects for management. Ocean \& Coastal Management, 51(6):463-468. doi:10.1016/j.ocecoaman.2008.04.004 